\author{
Yuriy Melnyk, \\ PhD in Pedagogy, associate professor, \\ professor of the Department of Psychology and Pedagogy, \\ National Academy of the National Guard of Ukraine, \\ 3, Zakhysnykiv Ukrainy Square, Kharkiv, Ukraine
}

\title{
STUDY OF TRENDS OF STUDENTS' DEMAND FOR THE FORMATION OF COMPETENCES BY HIGHER EDUCATIONAL INSTITUTIONS
}

Contemporary training of high-skilled specialists and providing their mobility at the European labour market requires studying and taking into account trends of the demand for the formation of students' competences by higher educational institutions. The paper aims to present European experience in classifying competences as well as results of studying trends of university students' demand for the formation of their competences at higher educational institutions of Ukraine. The following research methods were applied: information gathering (regular private written questionnaire), systematisation, ranked evaluation, results analysis and interpretation. Methodology and instruments for studying competences in higher education have been proposed in the research. In order to make the sample representative and obtain required information, the study was conducted among students and cadets taking into account individual, group and collective choice. The study was conducted during 4 academic years (2013-2017) at National Academy of the National Guard of Ukraine; 430 people (including 14 student groups and 12 cadet groups) participated in the study. The results obtained indicate that the most popular demand among university students is the formation of the following competences in them: determination and perseverance in the tasks given and responsibilities taken; ability to make reasoned decisions; ability to apply knowledge in practical situations; ability to work in a team; ability to adapt to and act in new situation; ability to plan and manage time; ability to evaluate and maintain the quality of work produced; ability to identify, pose and resolve problems; knowledge and understanding of the subject area and understanding of the profession; capacity to learn and stay up-to-date with learning. The determined demand trends for the formation of competences among university students of Ukraine was compared to the data obtained in studies conducted as part of the Tuning Project.

Keywords: students' demand, competence, classification of competences, instrumental competences, interpersonal competences, systemic competences, Tuning project.

\section{Introduction}

Intensive reforming of the system of higher education in Ukraine and the scale of current developments that have been declared by the new version of the Law of Ukraine "On Education" involve implementation of its provisions, systematisation of its numerous components, studying and taking into account trends of European educational space. This law provides the basis for the functioning of higher education system, creates conditions for enhanced cooperation between government bodies, business and higher educational institutions on the principles of autonomy of the latter, interconnection between education, science and manufacturing with a focus on preparing achievement-oriented human resources for high-technology and innovative development of the country, personality's self-fulfilment, meeting the needs of the society, labour market and the state in terms of high-skilled specialists. It is emphasised in the law that training specialists at higher educational institutions must take into account personality's needs, interests of the state, community and employers [1].

Therefore, one of the challenging tasks allotted by the state and society for higher educational institutions is determining the trends of social demand for competences and their formation in students in the process of training.
Obviously, there is a need in the society for trained specialists with a set of competences appropriate to present-day reality, which provide their personal and professional development, form the firm basis for the European and world integration.

Personality development and issues of the formation of competences in university students are covered in the works of R. Valeeva, N. Bushmeleva [2]. Interrelation of competencies and learning outcomes after university studies is reflected in the works of R. Wagenaar [3], R. Burganova, S. Abdugalina, K. Shaiheslyamova [4]. The research works of K. Meterbayeva, Zh. Karmenbayeva, M. Tleulinova, Z. Auhadieva, G. Yegimberdieva [5] have theoretical and practical importance for the development of pedagogical aspects of forming university students' competences. Classification of competences and their use in higher education are covered in the work "Competence-based learning. A proposal for the assessment of generic competences" [6]. The main sources of information concerning classification and study of competences, which are going to be considered in thus study, are materials provided by the Quality Assurance Agency for Higher Education, QAA, UK and Tuning educational structures in Europe, TUNING) [7]. 
It is the study of competences that was one of the key tasks of Tuning project initiated in 2000 by European universities (coordinator - University of Deusto, Spain) with the assistance of the European Commission. In the coming years it was updated with a number of regional projects: Tuning - Latin America (2003), Tuning - Russia (2006), Tuning - USA, Tuning - Lithuania, Tuning Africa, Tuning - Australia (2009). It should be noted that a specialised project Tuning SQF was implemented in 2007 with the purpose of developing sectorial framework of qualifications consistent with the framework of qualifications for the European Higher Education Area.

It is believed that competences are determined by experts and teachers taking into account employers' needs. However, nowadays students are becoming more well-travelled; they form demand for certain specialities and for the formation of certain competences in them.

It has been generally agreed to divide competences into two groups: subject specific competences and generic competences (transferable skills). This fact requires specification.

Based on experience of more than 100 universities from 16 countries participating in Bologna process (5183 graduates, 998 academics and 944 employers took part in consultations and questionnaires), 30 generic competences were selected from 3 categories: instrumental, interpersonal and systemic. They were classified depending on the significance of corresponding skills for a profession and the level of their mastering at the end of the study programme [8].

1. Instrumental competences include cognitive, methodological, technological and linguistic abilities, in particular: ability for analysis and synthesis; ability for organising and planning; basic general knowledge; acquisition of profession-related basic knowledge; oral and written communication in native language; command of foreign language; elementary computer skills; skills related to information management (ability to find and analyse information); problem-solving; decision-making.

2. Interpersonal competences include communication skills, social interaction and cooperation: ability for criticism and self-criticism; interaction (work in a team); interpersonal abilities and skills; ability to work in an interdisciplinary team; ability to communicate with experts from other fields; positive attitude towards cultural differences; ability to work in international environment; ethical obligations.

3. Systemic competences include combination of understanding, sensibility and knowledge; ability to plan changes for improving systems and developing the new ones: ability to put knowledge in practice; research abilities and skills; learning ability; ability to adapt to new situations; ability to generate new ideas (creativity); leadership qualities; understanding culture and customs of other countries; ability to work independently; planning and project management; initiative and entrepreneurial spirit; focus on quality; wish to achieve success.
Despite the specified set of competences proposed by European experts, which was divided into three abovementioned groups [8], the study of university students' demand for the formation of competences in the process of studying at Ukrainian universities still remains relevant.

The aim of the paper is to present European experience in classifying competences as well as results of studying trends of university students' demand for formation of competences at higher educational institutions of Ukraine.

\section{Research methods}

The following research methods were applied: information gathering, systematisation, ranked evaluation, results analysis and interpretation.

The study was conducted at National Academy of the National Guard of Ukraine; 430 participants (both male and female) formed 26 groups, including 14 student groups and 12 cadet groups.

The study involved the use of regular written questioning of students, which lasted for 4 academic years (2013-2017).

Fourth-year students and cadets of intramural form of study obtaining Bachelor's degree in humanities, management and administration, transport and transportation infrastructure participated in the questioning.

The respondents were offered to choose 5 the most important competences (from the list of 30 generic competences), which, in their opinion, must be formed in them by university teachers, and to range them. At the next stage, every participant had an opportunity to discuss his/her choice in groups and to find 5 common competences. The last stage was characterised by collective discussion of results in groups and approval of a rated list with 5 the most significant competences.

In order to obtain ranked score of students' and cadets' collective choice, we used algorithm for calculating mean values - weighted arithmetic mean. It was calculated on the basis of the values of changeable subject from 1 to 5 with account of weightiness. Besides, the values of the subject were represented as a variable distribution series, in which the number of units in the group of 10 competences (which were on top of the rating) was not the same. In this case, weighting was carried out in accordance with frequency ratio (weightiness of the competences from 1 to 5), which indicates how many times each variant is repeated. For this reason, when calculating weighted arithmetic mean for each chosen competence, all the values of weightiness within the range from 1 to 5 were multiplied by the frequency of their repetition, the products were added together, the sum was divided by the total of frequencies (15), i.e. overall total. For example, for the competence "ability to apply knowledge in practical situations" the weighted arithmetic mean was calculated as follows: 


\section{$\frac{5 \times 1+4 \times 3+3 \times 5+2 \times 4+1 \times 7}{5+4+3+2+1}=3,13$.}

The same calculations were applied for other competences of the chosen group. The highest value of the weighted arithmetic mean was rated 1 , and the lowest 10.

Obtaining integrated assessment in each group has made it possible to find out the trends of university students' demand for the formation of competences within the last four years in accordance with their specialities.

\section{Discussion}

It is important to provide definition for the term "competence". It is considered as a general ability based on capabilities, knowledge, values and experience gained in the learning process, which is manifested in learning outcomes at a certain stage [9].

Thus, competences are acquired by students and formed by teachers at the level of a separate subject as well as academic programme as a whole. It is the key point for studying trends of university students' demand for forming competences at higher educational institutions.

It is worth noting that the demand for the formation of competences by university teachers was analysed only after explaining the essence of each competence to students and cadets.

We used a specially developed questionnaire with the detailed list of competences according to three categories (instrumental, interpersonal and systemic ones).

The variants of students' answers were noted down in the table (Table 1).

The study of students' demand for the formation of competences by university teachers

\begin{tabular}{|c|c|c|c|c|}
\hline № & List of competences & $\begin{array}{c}\text { Preference 1 } \\
\text { (individual) }\end{array}$ & $\begin{array}{c}\text { Preference 2 } \\
\text { (group) }\end{array}$ & $\begin{array}{c}\text { Preference 3 } \\
\text { (collective) }\end{array}$ \\
\hline 1. & & & & \\
\hline 2. & & & & \\
\hline 3. & & & & \\
\hline 4. & & & & \\
\hline 5. & & & & \\
\hline$\ldots$ & & & & \\
\hline
\end{tabular}

General findings of studying collective preference in academic groups according to the above-mentioned generic competences from three categories are represented in the Table 2.

According to the results of the inquiry, the data obtained was systematised and the indicators forming the ranking of competences at higher educational institutions were calculated.

In our study, we used ranked evaluation method, which has a number of advantages: the use of certain indicators of competences in higher education that have been determined by a representative group of experts; multidimensionality of students' evaluation of competences; evaluating competences on the basis of public data received from students. This method is comparative, dynamic and simple for mathematical treatment of the scores obtained.

Using methods of mathematical statistics, general ranked score of students' and cadets' choice, which demonstrated their demand for the formation of competences at higher educational institutions of Ukraine, was calculated.

The results obtained indicate that among students and cadets of the National Academy of the National Guard of Ukraine, the most popular is the demand for the formation of the following competences: ability to plan and manage time; knowledge and understanding of the subject area and understanding of the profession; ability to identify, pose and resolve problems; ability to make reasoned decisions; ability to work in a team; ability to apply knowledge in practical situations, etc.

The demand for other competences was poorly expressed or absent.

Analysis of the data obtained demonstrates that instrumental and systemic competences are in demand among university students. As for interpersonal competences, the respondents mostly chose the ability to work in a team. The tendency that has been shown in our study absence of the demand for the formation of interpersonal competences among students of Ukrainian universities is consistent with the results presented by the European project Tuning. However, there are significant differences in terms of the formation of instrumental and systemic competences. 
Table 2.

\section{Research results of the inquiry of cadets and students regarding the formation of generic competences in higher education}

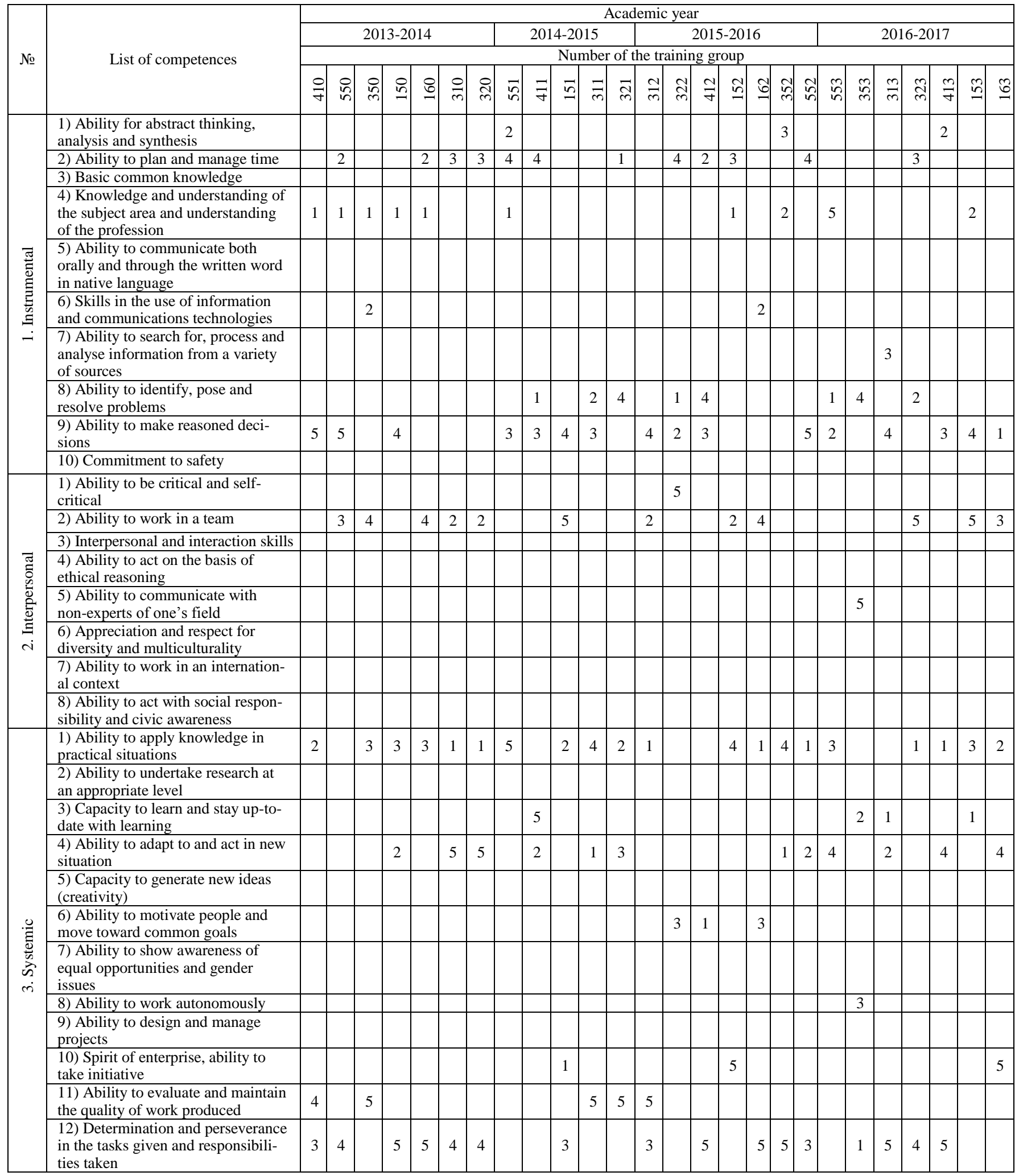


The results of comparing general ranked score of students' demand for the formation of generic competences at higher educational institutions according to Tuning project and among students of Ukrainian universities are presented in the Table 3

The results of comparing ranked score of students' demand for the formation of generic competences by higher educational institutions

\begin{tabular}{|c|l|l|}
\hline № & \multicolumn{1}{|c|}{ According to the European project Tuning [8] } & \multicolumn{1}{c|}{$\begin{array}{c}\text { The study conducted at Ukrainian higher educa- } \\
\text { tional institutions }\end{array}$} \\
\hline 1. & Ability for abstract thinking, analysis and synthesis & $\begin{array}{l}\text { Determination and perseverance in the tasks given } \\
\text { and responsibilities taken }\end{array}$ \\
\hline 2. & Capacity to learn and stay up-to-date with learning & Ability to make reasoned decisions \\
\hline 3. & Ability to apply knowledge in practical situations & Ability to apply knowledge in practical situations \\
\hline 4. & $\begin{array}{l}\text { Skills in the use of information and communications } \\
\text { technologies }\end{array}$ & Ability to work in a team \\
\hline 5. & Ability to adapt to and act in new situation & Ability to adapt to and act in new situation \\
\hline 6. & Interpersonal and interaction skills & Ability to plan and manage time \\
\hline 7. & $\begin{array}{l}\text { Ability to communicate both orally and through the } \\
\text { written word in native language }\end{array}$ & $\begin{array}{l}\text { Ability to evaluate and maintain the quality of } \\
\text { work produced }\end{array}$ \\
\hline 8. & Ability to make reasoned decisions & Ability to identify, pose and resolve problems \\
\hline 9. & Capacity to generate new ideas (creativity) & $\begin{array}{l}\text { Knowledge and understanding of the subject area } \\
\text { and understanding of the profession }\end{array}$ \\
\hline 10. & Ability to be critical and self-critical & Capacity to learn and stay up-to-date with learning \\
\hline
\end{tabular}

\section{Conclusions}

Our study demonstrates that the most popular competences are some of the instrumental and systemic ones. It can be explained by the specific character of the educational institution and facts of present-day Ukrainian life. Teachers should take into account students' demand for the formation of competences, which every university graduate must acquire, include them into the content of educational programmes, as long as there is correlation relationship between learning outcomes and competences. Studying the trend of students' demand for the formation of competences will contribute to prompt and flexible response to their needs. It will provide positive dynamics in the development of academic programmes that will become more focused on students' and employers' needs.

\section{REFERENCES}

1. Zakon Ukrainy "Pro vyshchu osvitu": pryiniatyi 1 lyp. 2014 roku № 1556-VII [Law of Ukraine "On higher education” dated July 1, 2014, № 1556-VII]. (2014, August 6). Holos Ukrainy - Voice of Ukraine, 148, 4-67 [in Ukrainian].

2. Valeeva, R. A., \& Bushmeleva, N. A. (2016). Forming analytical competency of higher school students. International Electronic Journal of Mathematics Education, 11(8), 3137-3148. Retrieved from: http://www.iejme.com/makale/925 [in English].

3. Wagenaar, R. (2014). Competences and learning outcomes: a panacea for understanding the (new) role of Higher Education? Tuning Journal for Higher Education:
Besides, it will improve the quality of educational programmes and qualifications. The competences that are properly defined and coordinated with all the participants of the educational process become its key factor and basis for training high-skilled young specialists.

The study does not cover all the aspects of studying competences formed by higher educational institutions. The following issues require further research: finding out demand of ministries and government departments, employers; coordination of the list of these competences with experts, etc. It is important to coordinate competences, which are formed as part of learning different subjects and evaluated at different stages, with the educational programmes.

Competence-based learning: a global perspective, 1(2), 279-302. doi:dx.doi.org/10.18543/tjhe-1(2)-2014pp279302 [in English].

4. Burganova, R. I., Abdugalina, S. E., \& Shaiheslyamova, K. O. (2016). The professional competence formation in the training process in higher educational institution. International Journal of Environmental and Science Education, 11(10), 3629-3639 [in English].

5. Meterbayeva, K., Karmenbayeva, Zh., Tleulinova, M., Auhadieva, Z., \& Egimberdieva, G. (2015). Pedagogical bases of professional competence formation of the future specialists. Procedia - Social and Behavioral Sciences,

185 ,

240-243 
doi:doi.org/10.1016/j.sbspro.2015.03.465 [in English].

6. Sánchez, A. V., \& Ruiz, M. P. (Eds.). (2008). Competence-based learning. A proposal for the assessment of generic competences. Bilbao: University of Deusto. Retrieved from: http://www.unideusto.org/tuningeu/images/stories/Publica tions/Book_Competence_Based_Learning.pdf [in English].

7. Tuning Association. (2010). A tuning guide to formulating degree programme profiles including programme competences and programme learning outcomes. Bilbao: Groningen and the Hague. Retrieved from: http://www.unideusto.org/tuningeu/images/stories/docum ents/Tuning_Guide._Degree_programme_profiles.pdf [in

\section{ЛІТЕРАТУРА}

1. Закон України Про вищу освіту : прийнятий 1 лип. 2014 року № 1556-VII // Голос України. - 2014. № 148. - 6 серп. - С. 4-67.

2. Valeeva R. A. Forming analytical competency of higher school students [Електронний pecypc] / R. A. Valeeva, N.A. Bushmeleva // International Electronic Journal of Mathematics Education. - 2016. Vol. 11. - Issue 8. - P. 3137-3148. Режим доступу : http://www.iejme.com/makale/925.

3. Wagenaar R. Competences and learning outcomes : a panacea for understanding the (new) role of Higher Education? / R. Wagenaar // Tuning Journal for Higher Education : Competence-based learning : a global perspective. - 2014. - Vol. 1. - № 2. - P. 279-302. doi:dx.doi.org/10.18543/tjhe-1(2)-2014pp279-302.

4. Burganova R. I. The professional competence formation in the training process in higher educational institution / R. I. Burganova, S. E. Abdugalina, K. O. Shaiheslyamova // International Journal of Environmental and Science Education. - 2016. - Vol. 11. - Issue 10. P. 3629-3639.

5. Meterbayeva K. Pedagogical bases of professional competence formation of the future specialists / $\mathrm{K}$. Meterbayeva, Zh. Karmenbayeva, M. Tleulinova, Z. Auhadieva, G. Egimberdieva // Procedia - Social and Behavioral Sciences. - 2015. - Vol. 185. - P. 240-243. doi
English].

8. Zakharchenko, V. M., Luhovyi, V. I., Rashkevych, Yu. M., \& Talanova, Zh. V. (2014). Rozroblennia osvitnikh prohram [Development of educational programs]. V. H. Kremen (Ed.). Kyiv: DP «NVTs «Priorytety» [in Ukrainian].

9. Melnyk, Yu. B. (2016). Doslidzhennia sotsialnoho zapytu kursantiv i studentiv shchodo formuvannia kompetentnostei $\mathrm{u}$ VVNZ [Investigation of the social request of cadets and students on the formation of competences in HMEI]. Aktualni pytannia osvity $i$ nauky - Current issues of education and science: Proceedings of the 4th International Scientific and Practical Conference. (pp. 280-288). Kharkiv: KhOHOKZ [in Ukrainian].

:doi.org/10.1016/j.sbspro.2015.03.465.

6. Competence-based learning. A proposal for the assessment of generic competences [Електронний ресурс] / in A.V. Sánchez, M.P. Ruiz (Eds.). - Bilbao: University of Deusto, 2008. - 336 p. - Режим доступу : http://www.unideusto.org/tuningeu/images/stories/Publica tions/Book_Competence_Based_Learning.pdf.

7. A tuning guide to formulating degree programme profiles including programme competences and programme learning outcomes [Електронний ресурс]. Bilbao: Groningen and The Hague, 2010. - 96 p. - Peжим доступу

http://www.unideusto.org/tuningeu/images/stories/docum ents/Tuning_Guide._Degree_programme_profiles.pdf.

8. Розроблення освітніх програм. Методичні рекомендації / В. М. Захарченко, В. І. Луговий, Ю. М. Рашкевич, Ж. В. Таланова; за ред. В. Г. Кременя. - К. : ДП «НВЦ «Пріоритети», 2014. $120 \mathrm{c}$.

9. Мельник Ю. Б. Дослідження соціального запиту курсантів і студентів щодо формування компетентностей у ВВНЗ / Ю. Б. Мельник // Актуальні питання освіти і науки : Матеріали IV Міжнародної науковопрактичної конференції (м. Харків, 10-11 листопада 2016 р.). - Х. : ХОГОКЗ, 2016. - С. 280-288.

Юрій Борисович Мельник, доктор філософії з освітніх наук (PhD), доцент, професор кафедри психології і педагогіки,

Національна академія Національної гвардії України, майдан Захисників Украӥни, 3, Харків, Украӥна

\section{ВИВЧЕННЯ ТЕНДЕНЦЙ ЗАПИТУ НА ФОРМУВАННЯ КОМПЕТЕНТНОСТЕЙ У ВИЩИЙ ШКОЛІ СЕРЕД СТУДЕНТСЬКОЇ МОЛОДІ}

Сучасна підготовка висококваліфікованих фахівців і забезпечення їхньої мобільності на Європейському ринку праці вимагає від вищих навчальних закладів вивчення та врахування тенденції запиту на формування компетентностей у студентської молоді. Метою статті є висвітлення Європейського досвіду класифікації компетентностей, результатів дослідження тенденцій запиту студентської молоді щодо розвитку у них загальних компетентностей у вищій школі України. Для вивчення тенденції запиту на формування компетентностей у студентської молоді використано комплекс методів: метод збору інформації 
(систематичного закритого письмового опитування), систематизації, рейтингового оцінювання, аналізу і тлумачення результатів. У дослідженні запропоновано методику та інструментарій для вивчення компетентностей у вищий школі. Задля забезпечення репрезентативної вибірки та отримання необхідної інформації опитування проводилось серед студентів та курсантів із урахуванням індивідуального, групового, колективного вибору. Дослідження проводилось протягом 4 навчальних років (2013-2017 р.р.) на базі Національної академії Національної гвардії України, загальна кількість респондентів - 430 осіб (14 - груп студентів, 12 - курсантів). Результати дослідження свідчать, що найбільш затребуваними серед студентської молоді $є$ попит на формування у них викладачами таких компетентностей: рішучість та наполегливість у виконанні поставлених завдань та взятих на себе зобов'язань; здатність приймати обгрунтовані рішення; вміння застосовувати знання в практичних ситуаціях; вміння працювати в команді; здатність адаптуватися та діяти в новій ситуації; здатність планувати і керувати часом; уміння оцінювати та підтримувати якість виконаної роботи; здатність виявляти, ставити і вирішувати проблеми; знання та розуміння предметної області та розуміння професії; вміння навчатися та бути в курсі останніх подій. Визначені тенденції запиту на формування компетентностей у вищий школі серед студентської молоді України порівняно 3 даними, отриманими в рамках досліджень за європейським проектом Тюнінг.

Ключові слова: запит студентів, компетентність, класифікація компетентностей, інструментальні компетентності, міжособистісні компетентності, системні компетентності, проект Тюнінг.

Doctor of Psychology, prof. I. Prykhodko

Submitted on April, 28, 2017

UDC: $37.015 .311: 378$

DOI: https://doi.org/10.24195/2414-4665-2017-5-23

Roman Popov,

PhD (Public Administration), associate professor, Department of Romance and Germanic Languages and Translation, National University of Life and Environmental Sciences of Ukraine 15, Heroiv Oborony Str., Kyiv, Ukraine

\section{SELF-ACTUALIZATION AND SELF-FULFILLMENT IN THE CONTEXT OF STUDENTS' AUTONOMY DEVELOPMENT WITHIN THE EDUCATIONAL PROCESS}

The article highlights important qualities that contribute to the effective development of autonomy of students in higher educational institutions. During the development of students' autonomy in the educational process the opportunities for the formation of their creativity, independence and ability to make decisions concerning the solution of certain theoretical and practical pedagogical problems greatly increase. Self-actualization is not a static condition, it is an active process in which person's capacities are used to their fullest. Creativity, ingenuousness, courage and hard work are the major characteristics of people, who are capable of self-actualization. The self-actualization is of special importance in professional activities, and for that it is not only necessary to possess the mentioned qualities but also to have the necessary professional tools and knowledge which will provide the performance and efficiency of work as well as capacities for professional growth.

Key words: self-actualization, self-realization, self-efficacy, the development of autonomy of students, selfregulation.

\section{Introduction}

Innovative teaching technologies, practical implementation of modern approaches to rapidly changing information submission require future lecturers to be independent and mobile in taking their decisions concerning the large variety of unconventional pedagogical tasks which they can face during their teaching practice. In order to feel confident in the volatile educational space the future lecturers should acquire firm skills in selfactualization and self-fulfillment in the process of their studying at higher educational institutions, which will later become the indices of their self-efficiency on the way to self-perfection.

A prominent Western psychologist of the $20^{\text {th }}$ century, one of the creators of the personality theory, A. Adler, indicated that we react actively and creatively to all the influences we face [1]. We do not remain in the state of inert and passive objects, but rather actively search for certain kinds of feelings and despise other ones. We selectively systemize and comprehend our experience, choose an individual scheme of apperception and form a clear model of our attitude towards the world, thus actively and 